\title{
Risk Management and Insurance Practices in Protecting the GCC Economies: Impact of Climate Change
}

\author{
Prof. Saad Darwish (PhD) \\ Applied Science University, Kingdom of Bahrain
}

Doi: 10.19044/esj.2018.v14n13p165 URL:http://dx.doi.org/10.19044/esj.2018.v14n13p165

\begin{abstract}
Climate change can extremely influence the progress of the Gulf Cooperation Council (GCC) nations by aggravating the burden on these states, hence, preventing them from accomplishing their economic progression. The extreme hotness and abridged precipitation will aggravate the water shortage and upsurge the occurrence of droughts. This would unfavorably influence the food production and deteriorate the present condition of food security and other related issues. The GCC area is anticipated to have more unembellished effects of Sea Level Upsurge than any other state. The current global warming has the potential of putting 6-25 million people and vital economic activities to coastal flooding. The area is one of the highly built-up states of the world. Climate change is one of the biggest challenges that humanity is facing, as it is not only a threat on biodiversity and food security, but is also impeding economic performance and growth. It is worth saying that climate threats are all interlinked. Good examples of the effects of climate change are: global temperature rise, warming oceans shrinking ice sheets, glacial retreat, decreased snow cover, rise in sea level, declining arctic sea, ice ocean acidification, and desertification. This paper focuses on giving attention to decision makers on the seriousness of these risks and to point out how risk management and insurance techniques can help in the survival of their economies. Furthermore, it also opened avenues for universities to get involved in this research area.
\end{abstract}

Keywords: Climate Change, Insurance, Risk Management

\section{Introduction}

Changes in climate may aggravate already existing challenges of water scarcity, food security, and, above all, population growth in GCC countries. Loss of biodiversity, desertification, and rise in sea level are some of the other pitfalls that may accompany environment change. Scorching temperatures, 
extreme humidity, and damaged arid lands are the characteristic features of the region. Salt intrusion in the aquifers is a major consequence of these conditions having wide ranging impact on agriculture, particularly small scale agriculture, which in turn is aggravating the threat to food security in the region. However, these threats to environment, livelihood and economy have impelled GCC states to participate actively in global consultations for environmental trepidations (Al-Maamary et al., 2017). Climate change has already started to show its effects as even a few-day-rain floods bring life in various metropolitans of the region to a halt. Thus, these threats to GCC climate warrant immediate and necessary actions.

\section{Research Methodology}

This study uses the interpritivist methodology. It focuses on describing the current situation of climate change in the GCC States through the use of secondary data and literature that discusses the role of risk management and insurance in protecting the GCC member economies. For this purpose, the researcher scrutinized many sources and some statistics in order to contribute towards answering the questions raised by the researcher.

\section{Climate Change Issues in the GCC Rise in Sea Level}

As almost all the countries located in the Arabian Peninsula border the ocean at least on one side, sea level rise is the major concern for countries of this region. Islands, both large and small, are particularly vulnerable to this threat. The Bahrain's island is a case in point as it has witnessed intense industrial and residential activities in recent years. This widespread commercial movement has come at the cost of extensive land reclamation in coastal areas. Coupled with its low-lying geology, the island is a peculiar example of serious threats that sea level rise is posing to this region. Bahrain Supreme Council for the environment has revealed that large area of land may be inundated as a consequence of various climate changes. About five percent $\left(36 \mathrm{~km}^{2}\right)$ of the total area of Bahrain may get inundated by 2100 even by a low sea level rise. The area under threat may increase to $11 \%\left(69 \mathrm{~km}^{2}\right)$ of total Bahrain land in worst case scenario. The effect of inundation on the vulnerable infrastructure in five major islands of Bahrain will be uneven and may have disastrous effects on roads, cultivable land, as well as on beaches and salt marshes. Even in other metropolises, such as Dubai, increasing sea levels may harm coastlines if reinforcement measures are not implemented (Mills, 2014).

\section{Water Availability}

Groundwater reserves in GCC states are rapidly depleting mainly due to continued use of non-renewable water, thus exposing countries of this 
region to great harmful effects of climate change. The water in Saudi Arabia is drawn from four sources: groundwater from deep fossil aquifers, desalinated water, surface water, and reclaimed wastewater. Among these, reliance on groundwater from deep aquifers is most damaging for the environment as this source is non-renewable and is already overburdened and exhausted due to uncontrolled usage in the past three decades. Agricultural activities account for approximately $85 \%$ of water usage in Saudi Arabia. Therefore, any threats to water availability may lead to disastrous consequences on the livelihoods and food security of people living in these areas.

The Bahrain was well-known for freshwater springs as well as its productive lands. However, rapid urbanization has led to the loss of precious natural resources, more importantly the groundwater. Similarly, increasing water shortage has forced Qatar to rely on desalination plants for supply of freshwater. In addition to Qatar, majority of GCC countries have increasingly been installing these energy intensive plants. These plants have proved to be a heavy burden to the atmosphere.

\section{Food Security}

Increasing food prices are a particular concern for the Middle East due to water shortage and nature of train. Cultivation of new land is challenging. Currently, only about $2 \%$ of Saudi Arabia's vast land is arable, and that is only possible after heavy investment in modern irrigation and farming technologies. According to estimates, the population of Saudi Arabia may increase by as much as $77 \%$ by 2050 , thus dwindling water reserves and make the land difficult to cultivate land; this, however, results to insufficient food production that would be enough for such number of people (Stang, 2016). More than 6,000 people are employed in the fishing sector in Bahrain. Destruction of coral reef habitats will have devastating effects on fauna and fish stocks in this region, thus threatening the feasibility of fishing industry in Bahrain. Climate change may also impact Bahrain in another way. Even a one meter increase in sea level may lead to loss of $11 \%$ of the total cultivable agricultural land in the country.

\section{Biodiversity}

One of the mostly overlooked aspect of environment change is its adverse impact on biodiversity. Any potential damage to the natural surroundings in GCC region may also affect biodiversity in the region. The Arabian Peninsula is situated at a confluence of Indo-Pacific and AfroEuropean regions and is home to a diverse range of mammalian, avian, amphibian, and reptilian species. 
Moreover, the comparative shallowness of Arabian Gulf also serves as a supportive coastal habitat for unique marine life including intertidal mudflats, sea grasses, mangroves, algae, coral reefs, and, above all, a wide variety of fish species. Climate change is likely to unfavorably affect all these species. Some of which are already considered to be endangered. Seasonal migratory birds and dugongs are also an important part of the rich ecology of this region, whose survival is being threatened by climate change.

From an ecological point of view, the effects of environment change on Gulf region may be insignificant compared to other parts of the world, especially in terms of calamitous adversities like hurricanes, tsunamis, and floods etc. However, the economic bearing of climate change among countries of GCC region may be more severe due to high dependency on proceeds from oil and gas exports. As the other countries will shift towards the use of more renewable sources of energy due to obvious concerns and climate change, the economy of GCC nations will be badly affected due to decreasing oil and gas exports.

Fossil fuels are the foremost source of carbon dioxide $\left(\mathrm{CO}_{2}\right)$ emissions; and countries in the Gulf region are confronted with a problematic state of affairs as their economies are almost completely reliant on oil, gas, and petrochemical productions. Although these countries enjoy high rates of development, scarcity of arable land and water resources impedes the development and expansion of carbon sinks, forests, and green areas that can curtail the harmful changes to climate (Asif et al., 2015; Rouchy et al., 2017).

Figure 1.1. GCC scenario

Source: (Weforum.org, 2010)

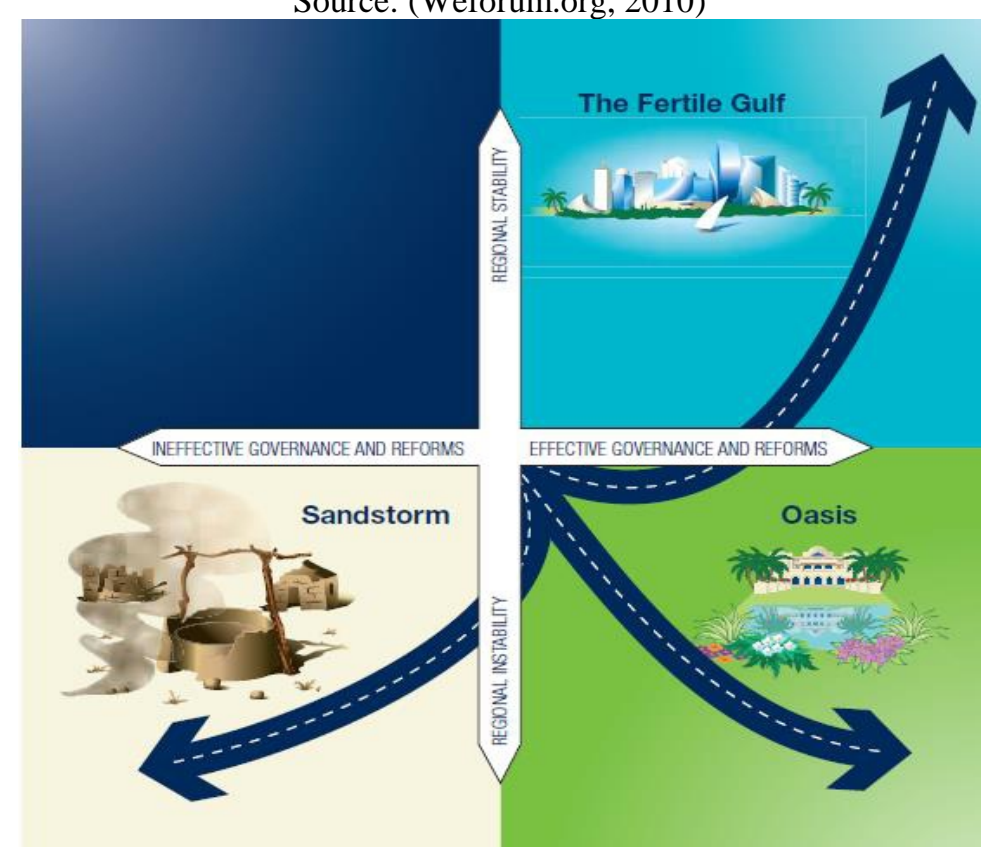


The desert spring depicts a situation where provincial dependability presents a test for the GCC nations and demands to accomplish generous institutional changes. The GCC nations cooperate to arrange conciliatory and monetary strategies through technocratic administration and a solid inward market. The over-direction moderates the procedure of globalization and affects the GCC nations. Although, they are a desert garden of security and flourish in a generally beset area.

The dust storm portrays a future, whereas regional shakiness is a characterizing factor. This influences the capacity of GCC nations to do genuinely necessary institutional changes. The changes are very slow because of an absence of thoughtfulness in a discouraging worldwide condition regarding the main driver of inward issues. There is also inclination for governments to concentrate on soundness to the detriment of long haul arrangements. The GCC nations are blinded and unfit to explore out of the dust storm and to distinguish open doors for flourishing for their populaces. The Fertile Gulf depicts the ascent of the GCC nations as development centers in a worldwide situation portrayed by solid interest for vitality and expanding globalization. The local strength gives the GCC countries the chance to concentrate on improving their human capital at all levels. This also creates the need for intense training and the continuing of deliberations towards political and institutional changes in order to help their developing economies and social orders (Reiche, 2010; Jammazi \& Aloui, 2015; Tariq, 2015; The Economist Intelligence Unit, 2010; Weforum, 2010).

Table 1.1. Greenhouse gas emissions in the GCC countries

Source: (World Resources Institute (WRI), 2014)

\begin{tabular}{|c|c|c|c|c|c|c|}
\hline $\begin{array}{c}\text { Emissions } \\
(2000), \\
\mathrm{MtCO}_{2} \mathrm{e} \\
\text { self- } \\
\text { reported }\end{array}$ & $\begin{array}{c}\text { Emissions } \\
(2000), \\
\mathrm{MtCO}_{2} \mathrm{e} \\
\text { per WRI }\end{array}$ & $\begin{array}{c}\text { Emissions } \\
(2010), \\
\mathrm{MtCO}_{2} \mathrm{e} \\
\text { per WRI }\end{array}$ & $\begin{array}{c}\text { Share of } \\
\text { global } \\
\text { total } \\
(2010) \\
\text { per WRI }\end{array}$ & $\begin{array}{c}\text { Per capita } \\
\text { (2010), } \mathrm{tCO}_{2} \mathrm{e} \\
\text { (global rank) } \\
\text { per WRI }\end{array}$ & $\begin{array}{l}\text { Emission } \\
\text { growth } \\
\text { I TPES growth, } \\
\text { CAGR 2000-10 }\end{array}$ & $\begin{array}{l}\text { Population } \\
\text { growth } \\
\text { / GDP growth, } \\
\text { CAGR 2000-10 }\end{array}$ \\
\hline \multicolumn{7}{|l|}{ Bahrain } \\
\hline 22.37 & 17.36 & 34.81 & $0.1 \%$ & $27.58(14)$ & $7.2 \% / 5.3 \%$ & $6.5 \% / 5.9 \%$ \\
\hline \multicolumn{7}{|l|}{ Kuwait } \\
\hline $\mathrm{n} / \mathrm{a}$ & 138.88 & 196.50 & $0.4 \%$ & $71.80(1)$ & $3.5 \% / 5.9 \%$ & $4.6 \% / 4.7 \%$ \\
\hline \multicolumn{7}{|l|}{ Oman } \\
\hline $\mathrm{n} / \mathrm{a}$ & 63.04 & 90.41 & $0.2 \%$ & 32.49 (11) & $3.7 \% / 9.5 \%$ & $2.5 \% / 4.9 \%$ \\
\hline \multicolumn{7}{|l|}{ Qatar } \\
\hline $\mathrm{n} / \mathrm{a}$ & 26.97 & 74.69 & $0.2 \%$ & $42.46(6)$ & $10.7 \% / 8.0 \%$ & $11.4 \% / 12.4 \%$ \\
\hline \multicolumn{7}{|l|}{ Saudi Arabia } \\
\hline $283.31^{i}$ & 296.73 & 542.10 & $1.2 \%$ & $19.75(22)$ & $6.2 \% / 5.3 \%$ & $3.1 \% / 5.4 \%$ \\
\hline \multicolumn{7}{|l|}{ UAE } \\
\hline 119,89 & 110.56 & 256.27 & $0.6 \%$ & $34.12(9)$ & $8.8 \% / 6.2 \%$ & $10.8 \% / 3.9 \%$ \\
\hline \multicolumn{7}{|l|}{ World } \\
\hline $\mathrm{n} / \mathrm{a}$ & $38,224.71$ & $47,182.61$ & $100 \%$ & $6.84(-)$ & $2.3 \% / 2.3 \%$ & $1.2 \% / \mathrm{n} / \mathrm{a}$ \\
\hline
\end{tabular}

Consequently, the latest releases of information are absent for examination in this regard. The analysis depends on information gathered by 
the World Resources Institute (WRI), the International Energy Agency (IEA), and the US Energy Information Administration (US EIA). In chronicled terms, the combined $\mathrm{CO}_{2}$ discharges of each of the six GCC states from 1850 to 2007 speaks of just $0.04-0.58$ percent of the world total. In display terms as well, the GCC countries are little producers as far as aggregate current GHG outflows, with discharges of the five littler states signifying approximately 1.5 percent of aggregate worldwide outflows, as appeared in Table 1.1. As indicated by the WRI in 2010, Saudi Arabia (1.2 percent) was positioned as the world's seventeenth most elevated producer ahead of various nations with considerably bigger populaces, for example, Italy, Spain, and Turkey.

\section{Legislations in GCC regarding Climate Change}

The Middle East governments are gradually considering the issue of climate change. They are showing it as an uncontroversial point to a great extent that requires specialized arrangements of lethally imperfect "technopositive thinking". The various substantial scale, squeeze neighborly ventures are being manufactured. They include Saudi Arabia's King Abdullah City for Atomic and Renewable Energy and Masdar City close to Abu Dhabi. They are "Intended to be zero-carbon and zero-squander, home to a populace of 40,000 individuals, 50,000 suburbanites, in a territory of six square kilometers". The Masdar city is "assuming a pivotal part in the improvement of maintainable plan and innovation", as mentioned by Susan Lee from the University of Birmingham. Huge numbers of the important changes will be troublesome for rulers in the Middle East. Professor Robert Looney from the Naval Postgraduate School in California who dissected the Economic Intelligence Unit's Democracy Index and the World Energy Council's Energy Trilemma Index, clarified that popularity based governments "will probably consent to worldwide assertions that set particular focuses for carbon understandings" and "give ecological manageability need over either vitality security or reasonable vitality supplies". The administrations will constantly need vitality security since rising fuel costs poses the threat of social agitation (Sinclair, 2016).

\section{Role of Insurance Companies in GCC}

This sector has encountered consistent development which is based on economic progress, populace extension and enhanced regulatory conditions. The low insurance entrance offers plentiful chances to insurers in the GCC, regardless of solid fundamental development drivers. The region's insurance sector is likewise anticipating structural changes in the future. This is in accordance with positive regulatory advancements and endeavors towards achieving more noteworthy operational scale and productivity. The Alpen Capital published a recent report on the GCC Insurance industry and 
highlighted a number of opportunities for bigger players, leading to marginalization of smaller players in the industry. There are also several foreign insurance companies who are creating their footmark in the sector. An evidence of emerging risks in GCC is also examined by KPMG (2016)

\section{The GCC Risk Management and Insurance Industry Outlook}

The American Meteorological Society defined this risk management process as "climate change risk management approaches." However, this generally falls into four broad categories:

1) Mitigation-efforts to reduce greenhouse gas emissions;

2) Adaptation-increasing society's capacity to cope with changes in climate;

3) Geoengineering or climate engineering-additional, deliberate manipulation of the earth's system that is intended to counteract at least some of the impacts of greenhouse gas emissions;

4) Knowledge-based expansion - efforts to learn and understand more about the climate system, which can help support proactive risk management."

Government official in GCC must follow the above-mentioned categories. This could be done by establishing professional bodies with high support and budgets to prepare their economies for future fluctuations in the climate. The only distinguished role which is clear and would help the risk management process is the concept of transferring risks via insurance and reinsurance practices. Therefore, the "Alpen Capital" gauges the insurance business in the Gulf by expanding at a compounded yearly growth rate (CAGR) of $18.1 \%$ in the vicinity of 2012 and 2017. This aims to achieve a size of US\$ 37.5 billion, divided between life (US\$ 2.4 billion) and non-life (US\$ 35.1 billion) sections.

The disaster protection share is required to advance at a yearly normal proportion of around $2 \%$ amid this period. The non-life portion is estimated to develop at a substantially higher rate of $20.0 \%$ every year. The market share in this way is increasing from $86.6 \%$ out of 2012 to $93.6 \%$ out of 2017 .

The non-life insurance sector profits more due to persistent building and structure undertakings. The big share of oil incomes in the GCC nations is consumed for the improvement of the non-oil sector to support monetary broadening. This contributes to the development segment and to the non-life insurance sector. The greater entrance of health protection and development of vehicle cover are likewise liable to help the sector's development (Al-Amri, 2015).

The growth of insurance sector in GCC countries is expected to increase from $1.1 \%$ in 2012 to $2.0 \%$ by 2017 . The industrial development serenely surpasses the growth of GDP extension. The non-life insurance is 
viewed as the primary driving variable, which is probably going to surge from $0.9 \%$ to $1.9 \%$ amid the period.

The insurance business in the Gulf by 2017 is foreseen to dramatically increase from the 2012 as the huge number of individuals and organizations are availing insurance cover. The density of insurance industry is probably going to rise from US\$ 367.3 in 2012 to US\$ 751.4 in the year 2017. Notwithstanding, the difference among the life insurance and non-life is anticipated to broaden considerably.

The major insurance marketplaces in the GCC are KSA and UAE. Saudi Arabia may exceed the United Arab Emirates (UAE) as the chief insurance marketplace in the area. The Saudi insurance business is perceived as a foremost factor behind progression of the GCC insurance sector. The market is projected to grow at a Compound Annual Growth Rate of $26.5 \%$ between 2012 and 2017.

\section{The UAE Insurance Market}

The insurance market in the UAE is accounting for $44.1 \%$ of the region's GWP in 2012 [2]. The annual growth rate is $9.6 \%$ between 2008 and 2012, which accounts for US\$ 7.2 billion. The life insurance market in UAE is the most developed system, but the non-life segment contributes major share of industry revenue. The recent years observe notable higher growth in life insurance segment than non-life. The penetration and density of life insurance and non-life insurance segment was $2.0 \%$, which accounts for US\$ 1298.8 respectively. The comparison of averages for these both industries indicates favorably against the GCC.

The main non-life insurance products in the UAE include property and motor insurance. The global financial crisis negatively impacted non-life insurance. The property insurance has still potential in person and commercial markets. The locals have invested in real-estate projects. The development projects of infrastructure continue to develop and cause increase in insurance coverage. The growth in cars ownership backed by the mandatory motor vehicle insurance makes insurance line to thrive. The life insurance mainly depends on the expatriate population in the country. The religious beliefs of locals also resist adoption of life insurance policy. The development of Takaful inspired the locals to show more demand in life insurance due to Sharjah compliant products.

Most of the insurance companies in UAE are public limited and owned by the government-holding. The regulations require these firms to be recorded as public joint-stock businesses and then registered by monetary markets like Dubai Financial Market or Abu Dhabi Securities Exchange. The rest of insurance market is private limited companies and branches of international firms functioning in the state from 2012. They include 61 chief insurers and 2 
reinsurers. Oman Insurance Co., Abu Dhabi National Insurance Co., and Orient Insurance Co. are amongst the important insurance firms in the UAE.

The new entry of foreign players in the insurance market of UAE is restricted by a number of stipulations by UAE Insurance Authority. This includes that already operating companies with branches are eligible to get the license of operation in UAE. This sets clear indication that new foreign insurers are ineligible for operations. The second requirement for the new insurers is to offer the products which are not being currently offered by the market. This is to make sure that the marketplace has a greater necessity for present insurance. The local sponsorship is also needed for the foreign company to setup and open branches. There is also a maximum permissible limit of $25 \%$ acquisition in domestic insurance market for overseas players.

There is another option for the foreign companies to setup branches and operate in UAE. This includes making offshore companies which are registered in DIFC. The civil and commercial laws are not applicable to the companies in these areas as compared to the rest of the country. The companies can have $100 \%$ ownership regulated by Dubai Financial Services Authority. The companies in DIFC cannot retail insurance products in other emirates of UAE except in the free zone. These companies can offer insurance coverage for companies in DIFC and other GCC countries.

The insurance companies mainly rely on reinsurance segment in the UAE and some companies need their complete threat cover to reinsurers. The limitations on DIFC-based external businesses for providing insurance services in the local marketplace have formed a noteworthy volume of reinsurance capability. The numerous global companies have developed reinsurance maneuvers in the free zone for getting access to the domestic marketplace.

The agents and brokers are mainly the distribution channels for insurance products. According to statistics in 2011, the numbers of insurance agents were 11 and 170 brokers in the country. The underdeveloped was Bancassurance due to legal uncertainly as compared to other well developed insurance markets in Dubai. Now it is becoming very popular and Bancassurance has observed durable development. The banking industry is now joining with the insurance firms to develop and provide a wide variety of insurance services.

The GCC Insurance industry has shown growth and upward trend. It is underdeveloped in comparison to world average and trail by large margin. The drivers of industry growth show strong future prospects for insurance industry. The expectations are positive in line with regulatory advances and struggles of key companies in reaching operative measure and high proficiency (Mills, 2015). 


\section{Key Growth Drivers}

The population is expanding in GCC along with the huge number of foreigners. The increasing life expectancy leads to the demand of insurance products and services. The maintained financial progress will probably help growth of the general salary levels of individuals. The GDP per capital at purchasing power equality (PPP) in all the Gulf nations in the vicinity of 2012 and 2017 is anticipated to practice an encouraging progress of $2 \%-4 \%$. This growth will ultimately increase the capacity of residents to purchase the automobile and residential properties. This causes the increase in demand for insurance products. The government also promotes the diversification of economy and presents new opportunities (Asif, 2016). The health insurance programs in different jurisdictions are made compulsory. This will probably generate robust development for insurers. The sales of the automobile are also high and this will cascade on insurance industry. The United Arab Emirates has implemented health insurance programs mandatory for many years, especially the medical insurance for the residents and expatriates of Abu Dhabi. These insurance regulations will become model for the rest of the states beginning with Dubai. The Takaful segment is growing appropriateness for insurance in the Gulf states. The evolution of this industry will bring positive changes in regularity framework and operational metrics. Resultantly, the Takaful family products will generate higher demand in the gulf. The sector expects a durable regaining and growth at a CAGR of $23.0 \%$ between 2011 and 2016 to US\$ 1.2 billion. The ambiguity of legislation in the state is the leading factor obstructing development in the industry. The UAE marketplace will continue to increase regardless of weaknesses in other regional markets. Saudi Arabia and United Arab Emirates are representing the $90 \%$ of the family Takaful in the Middle East and Africa in 2001. The Dubai International Financial Centre (DIFC) and Qatar Financial Centre (QFC) have meaningfully subsidized to the development of local insurance business. These two centers are the hub of many insurance, reinsurance companies, and insurance intermediaries (Mills, 2015).

\section{Trends and Challenges in Insurance Industry in GCC}

Enterprise Risk Management (ERM) in the gulf region is in the developing phase. However, the insurance corporations practice very robust and enthusiastic risk management processes. The competition from foreign players will increase in the near future. The foreign insurers will further augment their presence in the Gulf by exhibiting advanced practical knowhow, delivery competencies, client alignment, and monetary strong point (Muralidhar, 2010). The adoption of a unified insurance system is the second uprising trend. The insurance rates are standardized now across the gulf region due to unified schemes of automobiles. This will further help in the unification 
of the insurance sector. A new distribution channel is also a growing trend. The Banac assurance and online policy approval have become more popular as the modern distribution channels. The Islamic banks are emerging in Family Takaful products and becoming important an medium for marketing and sales. There is another trend of changing investment mix. The regional insurance companies have invested more in low-risk instruments to reduce their exposure to equities. This will help to generate assured return on income and will reduce the risk and volatility in investment income. The insurance companies face number of challenges in GCC region. The size of the insurance market in the gulf region is limited and over-crowded by many domestic and international companies. There is high competition between automobile and healthcare insurance companies. The governing policies are considered inadequate in Gulf insurance industry. The major irregularity is found in the context, which is a lesser amount of refined solvency directives, stumpy principles of transparency, and inadequate guideline to standardize the investment of the insurer. The overall region regulation was found to have a wide range of discrepancies. The GCC has shown a downtrend in industrywide profit for several years. This mainly indicates low productivity in practical procedures, an incompetent working model, little scalability, and dropping investment earnings. There is a lack of skilled workforce in the insurance sector. This deficiency affected the companies' risk bearing capabilities and resulted in the increase of their operating overheads. The GCC consumers and small businesses have low awareness about the benefits of insurance. They are unable to realize that insurance is an effective means of protection of their wealth, health, savings, and security. The economic uncertainty of the world also presented great challenges to the insurance companies by creating uncertainty on returns. Further, the Eurozone's debt disaster prepared the request for maritime insurance. The Arab revolution has delicate apprehensions of general politically aware unpredictability in the Middle East area. The reappearance of such happenings may disturb the overall commercial and investment environment, and reason an unexpected point in insurance-related privileges.

\section{Risk Management Practices in GCC}

The marketplace regulation matters and policies will vary by industry to alleviate the effects of climate challenges. The solvency risks are very significant to all insurers. The financial constancy of the insurer is reliant on investment portfolio. Therefore, the insurance regulator has a universal worry over the solvency risk that environment-change-driven weather-related risks pose to insurers. This creates significance in order to inspect how environmental change will influence the investments insurers hold, and start appropriate regulatory standards for the investment performances of insurers. 
The assets of all insurers are characterized by the direct and indirect investments in real estate share. The life insurers grasp most of the direct investment the insurers have spent in real estate for the procedure of their own services and some indirect investments for revenue generation. These assets are mostly within the coastal zones, offering threat of climate change in practice of hurricanes and flooding. The worldwide environment change and upsurge of sea levels put a risk to structures in this region. There is pronounced investment risk for the insurer to invest in the properties in these regions. The insurer regulators want to identify the degree of weather related threats on real estate. This comprises deteriorating asset values and the costs of fortification, physical harm to structures, and related corporate interruption.

The reserves of the insurers are held by the investments in real estate projects. These indirect investments include mortgage-backed securities and pass-through securities. The change in climate is the biggest risk to these investment-based assets. The climate change causes catastrophes and leads the owners to mortgage defaults due to these stressful circumstances. Similarly, the premium increases or market withdrawal may also result in lack of affordable insurance coverage resulting in technical mortgage defaults. The investments of the insurer will be negatively affected due to non-availability of property insurance coverage.

The mortgage lenders may develop the property insurers, because they want insurance on property on which they grasp mortgages. The insurers also experience threat from investment in diverse sectors of economy like bonds, preferred stocks, and equities along with danger of investment in real estate in coastal zones. This industry has direct atmosphere and climate related damages to real estate properties along with extreme and over emission of pollution. The court has recognized the constraints of accountability of environment change to specific industry of economy. Municipal bonds, a momentous investment holding for many insurers, are another possible source of danger. The municipalities experience accumulative pressure and eventually accept the bearings of environment alteration.

\section{Conclusion}

This paper identified how climate change has affected the economy of GCC countries and how the insurance sector can help in creating economic stability in these countries. The Gulf Cooperation Council (GCC) countries have experienced remarkable social and economic advancement since the 1970s. The economic surplus from the energy segment has been directed into infrastructural expansion and for the development of the private sector. However, the GCC countries still require political, economic, social climate changes and development. These metropolitan centers have mega structure and weather shift will affect them catastrophically. The GCC nations are vastly 
awarded with oil and gas assets. The area is also respected for extraordinary potential of renewable energy means, mainly solar and wind that are less capitalized. The threat managing interventions, monetary streams, study of change, knowledge transfer, knowledge economy are all vigorous to meet the tests of weather variation. The insurance firms can play a great part in stimulating threat control strategies. The level of consideration of the situation of threat control differs meaningfully amongst the subjects and across the numerous segments of the object. The operative threat control necessitates an interdisciplinary methodology. Risk control necessitates competences, and therefore involves the specialists with a focus to advance and accomplish a portfolio of potential hazards. The threat control inventiveness performance, if correctly applied, will complete over time from strategic resolution to a tactical vital one. The definitive objective of enhanced enactment is to defend the economic welfares of GCC nations. Thus, climate change have far ranging effects on GCC countries.

\section{References:}

1. Al-Amri, K. (2015). Takaful insurance efficiency in the GCC countries. Humanomics, 31, 344-353.

2. Al-Maamary, H. M., Kazem, H. A. \& Chaichan, M. T. (2017). Climate change: The game changer in the Gulf Cooperation Council Region. Renewable and Sustainable Energy Reviews, 76, 555-576.

3. Asif, M. (2016). Growth and sustainability trends in the buildings sector in the GCC region with particular reference to the KSA and UAE. Renewable and Sustainable Energy Reviews, 55, 1267-1273.

4. Asif, M., Sharma, R. B. \& Adow, A. H. E. (2015). An empirical investigation of the relationship between economic growth, urbanization, energy consumption, and $\mathrm{CO} 2$ emission in GCC countries: a panel data analysis. Asian Social Science, 11, 270.

5. American Meteorological Society https://www.ametsoc.org/ams/index.cfm/policy/studiesanalysis/climate-change- risk-management/ Retrieved on the $15^{\text {th }}$ of July:2018;11;03

6. Jammazi, R. \& Aloui, C. (2015). On the interplay between energy consumption, economic growth and CO 2 emission nexus in the GCC countries: A comparative analysis through wavelet approaches. Renewable and Sustainable Energy Reviews, 51, 1737-1751.

7. KPMG (2016) Emerging Risks in the Global Insurance , KPMG International Cooperative

8. Mills, E. (2015). Responding to climate change - THE INSURANCE INDUSTRY PERSPECTIVE [Online]. Available: 
evanmills.lbl.gov/pubs/pdf/climate-action-insurance.pdf [Accessed August 16 2017].

9. Mills, R. (2014). Gulf climate change and irreversible sea level rise [Online]. Available: https:/www.thenational.ae/business/gulfclimate-change-and-irreversible-sea-level-rise-1.247685 [Accessed July 2017].

10. Muralidhar, K. (2010). Enterprise risk management in the Middle East oil industry: an empirical investigation across GCC countries. International Journal of Energy Sector Management, 4, 59-86.

11. Reiche, D. (2010). Energy Policies of Gulf Cooperation Council (GCC) countries - possibilities and limitations of ecological modernization in rentier states. Energy Policy, 38, 2395-2403.

12. Rouchy, N. et al. (2017). UAE Climate Change Risks \& Resilience : An Overview of Climate change risks to 12 Sectors.Available: https://greenarea.me/wp-content/themes/divi-child/reports/WWF.pdf

13. Sinclair, I. (2016). Gulf countries need revolutionary climate action, not glossy mega-projects [Online]. Available: https://ianjsinclair.wordpress.com/2017/01/13/gulf-countries-needrevolutionary-climate-action-not-glossy-mega-projects/ [Accessed July 2017].

14. Stang,G. ( 2016) Middle East Inst itute,Climate Challenges in the Middle East Rethinking Environmental , Cooperationoperation Series

15. Tariq Al-Olaimy (2015). Climate Change Impacts in GCC [Online]. EcoMENA. Available: http://www.ecomena.org/climate-change-gcc/ [Accessed April 5 2015].

16. The Economist Intelligent Units (2010). GCC to 2020. Available: https://warwick.ac.uk/fac/soc/pais/research/researchcentres/csgr/gree n/foresight/economy/2010_the_economist_the_gcc_in_2020__broadening_the_economy.pdf

17. Weforum.org. (2010). GCC Countries and the World: Scenarios to 2025

[Online].

Available: www3.weforum.org/docs/Scenario_GGCWorld2025_ExecutiveSum mary_2010.pdf [Accessed August 16 2017].

18. World Resources Institute (WRI) (2014). CAIT - Country Greenhouse Gas Emissions Data [Online]. Available: http://www.wri.org/resources/data-sets/cait-country-greenhouse-gasemissions-data [Accessed August 16 2017]. 